International Journal of Arts and Humanities Studies (IJAHS)

ISSN: 2754-4311

DOI: 10.32996/ijahs

Journal Homepage: www.al-kindipublisher.com/index.php/ijahs

\title{
Implementation of the Policy of Poverty Alleviation Acceleration Program in Bokat District, Buol Regency, Central Sulawesi Province, Indonesia
}

\author{
Ikhlasiani T. Tonggil ${ }^{1}$, Irawaty Igirisa ${ }^{2} \square$ and Arifin Tahir ${ }^{3}$ \\ ${ }^{1}$ Secretariat of the Regional House of People's Representatives of Buol Regency, Buol Regency, Indonesia \\ ${ }^{23}$ Faculty of Social Sciences, Universitas Negeri Gorontalo, Indonesia
}

$\square$ Corresponding Author: Irawati Igirisa, E-mail: irawati.igirisa.ung@gmail.com

ARTICLE INFO

Received: 02 October 2021

Accepted: 26 November 2021

Published: 28 December 2021

DOI: 10.32996/ijahs.2021.1.1.20

\section{KEYWORDS}

Implementation, Poverty

Alleviation Acceleration Program

Policy, Poverty Alleviation

\section{ABSTRACT}

The purpose of this study is to explore the implementation of the poverty alleviation acceleration program policy through the regional government's leading programs, especially maize commodity, in Bokat District, Buol Regency. It relied on a qualitative descriptive approach by revealing the phenomenon encountered by the farmers who received assistance in several villages, Bokat District. Data collection techniques involved interviews with several informants, continuous observations, and documents related to the poverty alleviation policy in Buol Regency. Further, data analysis was performed by data reduction and presentation, along with conclusion drawing. The results show that the policy has been implemented according to the predetermined stages through Regional Regulation Number 7 of 2015, including community outreach, business capital strengthening, empowerment, monitoring, and evaluation. However, it is found out that the policy is yet to be optimal. The community outreach conducted by the government has not been effective since only a few people took part. This stage also provides business capital strengthening by giving them processing fees, seeds, fertilizers, and pesticides. Still, both stages are only carried out in the first year at each location where the poverty alleviation acceleration program is promoted. In addition, an empowerment program that can support the development of maize commodity as the regional government's leading program has not been executed. Monitoring and evaluation of such a policy have not been entirely performed, impacting different levels of success each village reaches. On this ground, the poverty alleviation acceleration program policy needs to be re-evaluated to also detect any problems in the area, increase people's income, and bring success to the policy implementation.

\section{Introduction}

Poverty is a state in which a person or community cannot meet basic human needs, such as food, shelter, clothing, basic education, and health in a minimum standard. It is an urgent issue and requires systematic, integrated, and comprehensive steps and management approaches. Increasing people's income is among the efforts to reduce the poverty rate, contributing to poverty reduction and economic growth (GU, R., \& NIE, F. ying, 2021). In this context, the government has implemented policies to properly reduce expenses and fulfil human rights through equitable and sustainable development to create a better life.

Copyright: (C) 2021 the Author(s). This article is an open access article distributed under the terms and conditions of the Creative Commons Attribution (CC-BY) 4.0 license (https://creativecommons.org/licenses/by/4.0/). Published by Al-Kindi Centre for Research and Development, London, United Kingdom. 


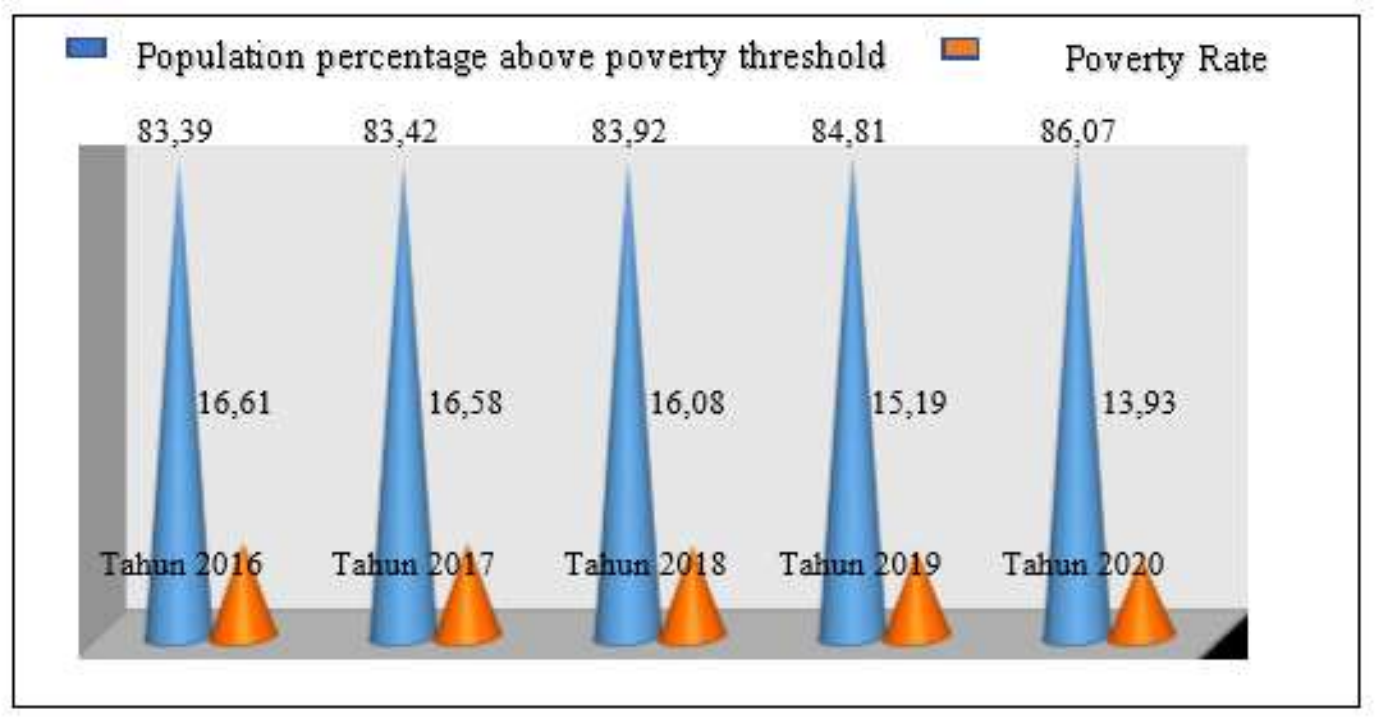

Table 1. Poverty Threshold and Poverty Rate of Buol Regency in 2016-2020

Source: RKPD of Buol Regency, 2020

Based on the population percentage above the Poverty Threshold and Poverty Rate of Buol Regency in 2016-2020, the poverty rate in this regency tends to decrease from year to year. The poverty rate in 2016 arrived at $16.61 \%$ and slowly dropped to $16.58 \%$ in 2017. Further, it became $16.08 \%$ in 2018 and $15.19 \%$ in 2019. Such a rate significantly fell to 13.93 percent in 2020 (RKPD Kabupaten Buol, 2020). Poverty is usually measured from the economic aspect and is multidimensional (Sutter, C., Bruton, G. D., \& Chen, J, 2019). Hence, it is essential to make policies that are expected to reduce poverty, such as the Poverty Alleviation Acceleration Program integrated with food crops, livestock, fisheries, and marine aspects. The policy intends to reach agricultural potentials integrated with other sectors in Buol Regency. Agriculture is an important source of income for most of the population (Bachev, H, 2006), a leading sector, and plays a significant role in the Indonesian economy (Igirisa, I, Rahman, M, Abdussamad, J, Abdusamad, Z, \& Husain, A. K, 2020). In this case, the farming community is given an assistance of land cultivation fees, corn seeds, fertilizers, pesticides, and agricultural equipment and marketing support for agricultural production.

The poverty alleviation acceleration program policy in Buol Regency is implemented in every district and village according to the village potentials. Bokat District, as one of the districts that developed the poverty alleviation acceleration program, is the research area that consists of 15 villages; nearly all villagers become the target of this program policy. The problem that emerged from this policy is that the farmers have not taken advantage of the facilities and assistance provided to them. Target group compliance is a crucial factor that defines the success of policy implementation (Akib, H, 2012). This is seen from how the success level of farmers in each village is different; some are able to improve the community's income, and the other way around. The inability to better the income indirectly impacts the poverty alleviation in Buol Regency.

\section{Literature Review}

\subsection{Public Policy}

Public policy is a guide to action and is connected with a broader framework that involves applying philosophies, principles, visions, and decisions through various programs, projects, and activities. A policy requires a comprehensive statement of future objectives and actions and disclosing ways to achieve them (Khan, A. R., \& Khandaker, S, 2016). A public policy regulates public life made by state administrators to solve public issues and arrive at desired goals and objectives. Such a policy always relates to the government's real action instead of what they want.

Mazmanian and Sabatier mention the stages of policy intervention as follows: 1) identifying the problem that needs to be intervened; 2) defining the objectives to be achieved; 3 ) designing the structure of the implementation process. On this ground, the program should be clearly arranged to be implemented. The process of public policy analysis, according to Dunn, is a series of intellectual activities carried out within a process comprised of activities that are essentially political. Moreover, Ripley states that the stages of public policy include: agenda preparation, policy formulation and legitimacy, policy implementation, and evaluation of implementation that focuses the policy environment on two variables, namely political culture and socio-economic (Kadji, Y, 2015). 


\subsection{Policy Implementation}

Implementation studies will delve into conflicts, complex decisions, and issues of what and how much one gets from a policy. Implementation is necessary to analyze policies (Igirisa, I., Rahman, M., Abdussamad, J., Abdusamad, Z., \& Husain, A. K, 2020). For this reason, policy implementation is considered an essential aspect of the entire policy process. An African policy expert, Udoji, has firmly said that policy implementation is crucial, perhaps more crucial than policymaking. If not implemented, policies will only be an aspiration or plan stored in the archive (Wahab, S.A 2017).

Danial A. Mazmanian and Paul A. Sabatier explain that understanding what happens after a program is applied or formulated is the focus of a policy implementation, i.e., giving real impacts on the community after the policy is validated (Wahab, S.A, 2017).

General understanding of policy implementation is stated by Grindle (1980) that implementation is a general process of administrative doings that can be examined at a certain program level. The implementation process will be started when the goals and objectives have been set, the activity program has been structured, and the funds are ready and distributed to reach the goals. Suppose such understanding is directed at the locus and focus (change) where the policy is implemented. In that case, it will be in line with Van Meter, and Van Horn cited by Parsons (1995) that policy implementation is an action taken by the government and private (organizations), both individually and in groups, intended to achieve the objective. (Akib, H, 2012).

Policy implementation includes actions by public or private individuals (or groups) that are directed at arriving at the objectives set out in previous policy decisions." In this context, policy implementation refers to achieving the policy objectives through the agreed planning and programming of operations. They view implementation as managerial or administrative issues and political processes related to who gets what, when, how, where, and from whom. Implementation is evolution if a person acts to implement a policy and then makes a change (Chigudu, D, 2015).

\subsection{Public Policy Implementation Model}

Policy implementation can be studied through several models of policy implementation as proposed by experts, including: (1) Policy implementation model by George Edward III (1980). He points out that "in our approach to the study of policy implementation, we begin in the abstract and ask: What are the preconditions for successful policy implementation? What are the primary obstacles to successful policy implementation?" To answer these substantial questions, Edward III offers and considers four factors in implementing public policy: "communication, resources, dispositions or attitudes, and bureaucratic structure" (Kadji 2015); (2) Policy implementation model by Van Horn and Van Meter (1975). This model presupposes that policy implementation runs linearly from the available political decisions, implementers, and public policy performances. According to Van Meter and Van Horn, the variables contributing to implementation performances are a). Policy standards and goals; b). Resources; c). Interorganizational communication and activity strengthening; d). Characteristics of Implementing agents; e). Attitudes / tendencies (disposition) of the implementers; f). Social, economic, and political conditions (Kadji 2015).

\subsection{Poverty}

Poverty serves as a global issue, and its alleviation has drawn the world's attention, particularly in developing countries (Leng, G. xiao, Feng, X. long, \& Qiu, H. guang, 2021). From the perspective of Administrative Science, poverty is the economic inability to meet people's average standard of living in a region. The inability is characterized by low income to fulfil basic needs, e.g., food, clothing, and housing. Low income will also affect the lack of ability to meet the average standard of living, namely health and education standards. The condition of a community considered poor is determined by their income ability to satisfy the standard of living.

In principle, the standard of living in a society is the fulfilment of the need for food and health and education. Decent housing is among a region's living standards or community welfare standards. From this condition, a community is considered poor if having income much lower than the average income, so that they do not have many opportunities to prosper themselves. Accordingly, the government provides personal assistance based on the identified causes of poverty to the poor (Cheng, X. yu, Wang, J. ying, \& Chen, K. Z, 2021).

Bastiaensen, De Herdt and D'Exelle (2005) opine that poverty is not an individual characteristic; instead, it characterizes a situation where a person or a group of people discover themselves at a point of time, making poverty a problem that social scientists and policymakers find difficult to overcome (Cobbinah, P. B., Black, R., \& Thwaites, R, 2013).

\subsection{Leading Commodity-based Regional Development}

Developing countries' development put more emphasis on economic development due to the economic backwardness. Economic development can support goal achievement or encourage changes or innovations in other fields (Hajeri, H., Yurisinthae, E., \& Dolorosa, E, 2015). Every region needs to determine areas and leading commodities following its potentials on this account. 
Each region owns different leading sectors. The development of leading sectors should consider a number of factors, including region characteristics, natural resource potentials, and human resource potentials (Mitrawan Fauzi, \& Luthfi Mutaali, 2017). The development of a commodity area is based on the Decree of the Minister of Agriculture Number 472 of 2018 concerning the Location of the National Agricultural Area, which stipulates prioritized commodity areas for food crops, horticulture, plantations, and livestock in all regencies. Agricultural sector in Indonesia serves as the strategic and important sector (Setiyanto, A., Irawan, B., \& Dabukke, F. B. M, 2020).

Leading commodities are strategic to be developed in a region whose establishment is based on technical (soil and climate conditions), socio-economic, and institutional (technology mastery, natural and human resource capability, infrastructure, and local socio-cultural condition) considerations. The maize commodity is designated as the leading commodity in Buol Regency.

\subsection{Poverty Alleviation Acceleration Program (PA2P)}

Presidential Regulation Number 15 of 2010 and its amendment of Presidential Regulation Number 96 of 2015 concerning Poverty Reduction Acceleration have become a reference for various ministries and regional governments to implement policies to reduce poverty. Poverty Alleviation Acceleration Program (PA2P) in Buol Regency is conducted by referring to Regional Regulation Number 7 of 2015 focusing on the agricultural sector by integrating the development of maize and cattle and strengthened by the development of leading commodities through farmer empowerment. Several previous studies have found that unsatisfactory poverty reduction acceleration blames the program management that is not integrated with each other (Nuraida, N., Rusli, B., Setianingrum, S., \& Rahmatunnisa, M, 2019).

The target of this program is poor households in one potential area, which will be organized in the form of a PA2P Farmer Group determined by the Regent. The purpose of implementing the PA2P include: (a) Optimizing the utilization of natural resources in an integrated manner; (b) Improving farmers' skills in utilizing the available natural resources to be more efficient and effective with simple technology; (c) Developing an eco-friendly and sustainable agricultural system; (d) Increasing farmers' income and bettering land productivity.

The objectives of implementing the PA2P are (a) Declining the poverty rate in Buol Regency; (b) The utilized potential and unused lands to develop plantation, agriculture, and livestock commodities; (c) Opening employment and business opportunities for poor households; (d) The utilized corn wastes for cattle feed with eco-friendly technology; (e) The increase in planting area and productivity of maize.

\section{Methodology}

This qualitative descriptive study involved local people in Bokat District, Buol Regency. It revealed the phenomenon a farming community as the target of the PA2P policy deals with, through observation of their activities, in-depth interview with the target, literature review, and documents regarding the focus of this research. Primary and secondary data were analyzed using qualitative data analysis.

Data analysis comprised the following stages: (a) Data reduction to simplify and correct the required data; (b) Presenting data in an organized and systematic manner to form an integrated component; (c) Interpreting the data as the determinant step in concluding (Sugiyono, 2019). The analyzed data were validated through data triangulation technique, extended observation, additional references, and focus group discussion.

\section{Results and Discussion}

As an urgent issue, poverty requires management to avoid its implication on a region's economy. Multiple indicators leading to poverty include occupation, land that is unable to grow crops due to limited working capital for fulfilling the family's economy, and insufficient facilities and infrastructure to support farmers' activities. Addressing these problems, the Regent implements policies that also serve as leading programs, such as the poverty alleviation acceleration program (PA2P) policy. This policy aims to reduce the relatively high poverty rate in Buol Regency. Therefore, the regional government carries out strategic efforts by stipulating the Regional Regulation Number 7 of 2015 concerning the Regional Leading Program-based Poverty Reduction Acceleration Program.

A leading sector is the driver of the economy (Hajeri, H., Yurisinthae, E., \& Dolorosa, E, 2015). The development of maize commodity as one of the Buol Government's leading programs intends to increase farmers' income. Research findings have designated all districts in Buol Regency as the target locations for the PA2P policy. Bokat District is one of the districts that became the locus of the present work. Out of 15 villages in Bokat District, 12 were the target of the PA2P policy, as shown in the table below. 
Table 1. The Target/Nontarget of PA2P in Bokat District

\begin{tabular}{|c|c|c|}
\hline No & Village & Description \\
\hline 1. & Bokat & Target \\
\hline 2. & Bokat 4 & Nontarget \\
\hline 3. & Bongo & Target \\
\hline 4. & Bukamog & Target \\
\hline 5. & Butukan & Target \\
\hline 6. & Duwamayo & Target \\
\hline 7. & Doulan & Target \\
\hline 8. & Negeri Lama & Nontarget \\
\hline 9. & Poongan & Target \\
\hline 10 & Kodolagon & Target \\
\hline 11 & Langudon & Target \\
\hline 12 & Tang & Target \\
\hline 13 & Tayadun & Target \\
\hline 14 & Tikopo & Target \\
\hline 15 & Kantanan & Nontarget \\
\hline
\end{tabular}

Data source: Bokat District Government, 2021

The PA2P policy in Bokat District is implemented through the following stages:

\subsection{PA2P policy community outreach}

In a public policy, community outreach is essential. It intends to familiarize an effort to the people for them to recognize and accept. In the context of public policy study, a policy that has been made should be recognized by the community to get their support and for the policy to be well-implemented. Community outreach is required to make people understand and comply with or get involved in the policy. (Herdiana, D, 2018).

The PA2P policy in Buol Regency has been started by conducting community outreach. Such involved several agencies, including Agriculture Service, district and village government, and the local community as the policy target. Community outreach was conducted in every target location of PA2P in the first year. However, it was not continued in the following year.

The result shows that the community outreach is considered ineffective as not all target villagers participated. Only some farmers were invited to the event, even they were not familiar with the PA2P policy since their village was not the policy target. A leading program should have been started with balanced community outreach in all districts and villages. Besides, the event was only conducted in the first year. For instance, the community outreach in Bokat District was performed only in 2016, along with the distribution of processing fees to all PA2P-targeted farmers.

It is also found out that the PA2P policy has not run optimally since a lot of vacant lands have not been used to grow maize as a leading commodity. Some farmers still carry out agricultural business by planting various plants, namely cocoa, rice, bananas, and others. This is also triggered by the mindset of the people who seem apathetic about the policy. For such reasons, community outreach is necessary as it plays the most significant role in implementing a policy.

Community outreach is done after a policy is made for the related parties to understand the purposes and objectives of its implementation so that it will be implemented as intended. The community outreach needs to be enhanced, leading the farmers to understand and support the PA2P policy implementation. Such can define the success of the PA2P policy that is expected to urge poverty alleviation. Poverty is usually measured from the economic aspect and is multidimensional; hence, community support for the previously-mentioned policy is required (Sutter, C., Bruton, G. D., \& Chen, J, 2019).

\subsection{Business capital strengthening}

Poverty is a serious problem closely related to economic growth and income distribution (Afridarman, Amar, S., \& Aimon, H, 2021). Economic sector strengthening in agriculture should be executed by providing working capital assistance to farmers. A business needs managed capital to support the activities of the business. Limited access to capital (credit) is among the factors causing poverty, which ultimately obstructs agribusiness activities' growth and profit (Yustika, 2013; Hermawan, H, 2019).

Efforts to strengthen business capital through expanding access to capital for farmers have not covered all areas in Bokat District. PA2P policy is yet to strengthen business capital for farmers, making them find additional business capital from capital owners or intermediaries. It is undeniable that intermediaries still dominate the life of farmers in Bokat District. This has become one of the options for the community to meet their funding needs for their business capital strengthening. In fact, the government provided 
capital strengthening through PA2P policy only in the first year (2016) in the form of business capital assistance, e.g., processing fees, seeds, fertilizers, and pesticides.

The next year, such assistance was no longer given to the farmers. Some farmers were only given seeds or other supporting facilities, such as maize drying tools, tractors, and the preparation of roads leading to the location of the maize commodity. This impacts the low interest of the farmers to continue their maize farming as the government's leading commodity.

In view of these findings, the implementation of the PA2P policy in several villages of Bokat District is unsuccessful. Simply put, the policy is not right on target and not consistent with its objectives, i.e., ensuring the protection and fulfilment of basic rights of the poor and reducing their expenses. Such a phenomenon indicates the unsuccessful implementation of the PA2P policy, specifically in maintaining the farmers' business stability. The government's failure to provide access to capital will prevent the community's condition from improving; they will remain poor. As a result of lack of capital, the farmers cannot sustain the agricultural production process.

\subsection{Community empowerment}

As a common issue in developing countries, poverty concerns the right to a decent life as a basic human right (Nuraida, N., Rusli, B., Setianingrum, S., \& Rahmatunnisa, M, 2019). PA2P policy is among the leading programs of Buol Regency government that increases income and poverty alleviation. The starting point of this policy is the development of maize commodities that must be supported by a community empowerment program. Farming community empowerment, including female farmers, is devoted to bettering the values and benefits of the maize commodity they produce. Women empowerment is a vital instrument in fighting poverty (Gu, R., \& Nie, F. ying, 2021).

The findings also suggest that farming community empowerment through PA2P policy in Bokat District is yet to be performed. An appropriate empowerment model through maize commodity utilization is expected to cultivate creativity, entrepreneurial spirit, and self-reliance. Empowerment activities should be carried out to enhance the community's creativity in processing maize by creating food diversification and processing corn waste (cornhusk and corncob) as the raw material for handicrafts with a higher economic value. However, the government and local community have not conducted these activities, although the corn production has increased. Maize commodity is one of the alternatives to staple food. In addition, this product can be diversified by combining it with other products (Andini, D.P, Pribadi, G, (2016).

As of today, the farmers solely sell the corn they produce without making any efforts to add the values and benefits of the corn. Community empowerment efforts in PA2P policy should have been executed earlier; thus, the corn produced gets more value. This will affect both the increase in people's income and poverty alleviation. The local community is expected to be more motivated to increase corn production and diversify processed corn products to add its values and benefits.

\subsection{PA2P policy monitoring and evaluation}

In a public policy, one of the critical stages is monitoring and evaluation of the policy implementation. Similarly, this stage is performed once a month for PA2P policy by the technical team from Agriculture Service or extension workers in the field. Monitoring and evaluation should have helped handle the hands-on problems. Both activities are integrated to control a program (Nurchasan, 2018).

Drawing upon the findings, monitoring and evaluation have not been fully conducted as regulated in PA2P policy. By doing this stage once a month, there should be no problems in the field. Many problems take place during the policy implementation in Bokat District, including the lack of support of the farmers, misuse of assistance, being apathetic towards the policy, and rejection of the policy. Such should not have occurred because the PA2P policy aims to increase farmers' income through maize commodity development.

Community outreach, processing fees, seeds, fertilizers, and pesticides provision as forms of business capital strengthening and community empowerment to support maize development in the research site should have been carried out properly. This will indicate the success of the PA2P policy and the increase in farmers' income. However, since the monitoring and evaluation stages of the PA2P policy have not been well-implemented, the policy is also less optimal. Even the farmers in some villages do not utilize the assistance properly. The village heads are not farmers, leading to the lack of support in developing maize commodities. Nevertheless, villages whose village heads are also farmers are quite successful. All the villagers have used their land to plant maize, and its production strongly affects the farmers' income increase.

The monitoring and evaluation stage should have been regularly carried out in order that PA2P policy implementation in Bokat District will achieve maximum success. Efforts to increase the income of the farming community through the empowerment and development of maize commodity as the leading product of the government are very relevant in supporting poverty alleviation in Bokat District, Buol Regency. In short, the implementation of the PA2P policy in Buol Regency is a series of stages, i.e., community 
outreach, capital strengthening, empowerment, monitoring and evaluation, which are expected to bolster the poverty alleviation in Buol Regency. Poverty is a relevant social problem to be studied continuously (Armoyu, H. M, 2013).

\section{Conclusion}

The poverty alleviation acceleration program policy has been implemented in Bokat District, Buol Regency. It has contributed to the increase in farmers' income, despite some stages being not optimally performed. Community outreach, capital strengthening, empowerment, and monitoring and evaluation, as the implementation stages conducted by the related services and farmers in the site area, are yet to be ideal. Nevertheless, some villages are very supportive during the policy implementation, creating a different success level of farmers in Bokat District. All farmers should have had the same impact and success level in the site area since they implement the same policy. This is a problem that needs an in-depth investigation to find the best solution for the farming community, and its impact will drive the poverty alleviation efforts in Buol Regency.

Funding: This research received no external funding

Conflicts of Interest: The authors declare no conflict of interest

\section{References}

[1] Afridarman, Amar, S., \& Aimon, H. (2021). Effect of Capital Strengthening, Education, and Health on Poverty Status in the City of Sawahlunto. Proceedings of the Sixth Padang International Conference On Economics Education, Economics, Business and Management, Accounting and Entrepreneurship (PICEEBA 2020), 179(Piceeba 2020), 236-244. https://doi.org/10.2991/aebmr.k.210616.035

[2] Akib, H. (2012). Implementasi Kebijakan: Apa, Mengapa dan Bagaimana [Policy Implementation: What, Why, and How]. Jurnal Ilmiah Ilmu Administrasi Publik, 1(1), 1-11. https://www.researchgate.net/publication/277844111 Implementasi_Kebijakan_Apa_Mengapa_dan_Bagaimana

[3] Andini, D.P, Pribadi, G (2016). Identification Of Corn Commodity to Maintain Sustainability Of Food Security, Study of Corn Commodities In Jember. Proceedings of The Second International on Food and Agriculture ISBN: 978-602-14917-9-997-103. https://publikasi. polije.ac.id/index.php/ProceedingICOFA/article/view/1810/1140

[4] Armoyu, H. M. (2013). Pemberdayaan Pendidikan Islam Sebagai Upaya Pengentasan Kemiskinan [Islamic Education Empowerment as an Effort of Poverty Alleviation]. Cendekia: Jurnal Kependidikan Dan Kemasyarakatan, 11(2), 233. https://doi.org/10.21154/cendekia.v11i2.278

[5] Bachev, H. (2006). Assessment of Farm Support Policies and Likely Impact of CAP Implementation on Farm Structures and Sustainability in Bulgaria. https://repository.kulib.kyotou.ac.jp/dspace/bitstream/2433/54318/1/724061.pdf

[6] Cheng, X. yu, Wang, J. ying, \& Chen, K. Z. (2021). Elite capture, the "follow-up checks" policy, and the targeted poverty alleviation program: Evidence from rural western China. Journal of Integrative Agriculture, 20(4), 880-890. https://doi.org/10.1016/S2095-3119(20)63444-X

[7] Chigudu, D. (2015). Navigating policy implementation gaps in Africa: The case of Zimbabwe. Risk Governance and Control: Financial Markets and Institutions, 5(3), 7-14. https://doi.org/10.22495/rgcv5i3art1

[8] Cobbinah, P. B., Black, R., \& Thwaites, R. (2013). Dynamics of Poverty in Developing Countries: Review of Poverty Reduction Approaches. Journal of Sustainable Development, 6(9). https://doi.org/10.5539/jsd.v6n9p25

[9] Gu, R., \& Nie, F. ying. (2021). Do empowering women to benefit poverty reduction? Evidence from a multi-component program in the Inner Mongolia Autonomous Region of China. Journal of Integrative Agriculture, 20(4), 1092-1106. https://doi.org/10.1016/S2095$\underline{3119(20) 63436-0}$

[10] Hajeri, H., Yurisinthae, E., \& Dolorosa, E. (2015). Analisis Penentuan Sektor Unggulan Perekonomian di Kabupaten Kubu Raya [Analysis of Determining Economic Leading Sector in Kubu Raya Regency]. Jurnal Ekonomi Bisnis Dan Kewirausahaan, 4(2), 253. https://doi.org/10.26418/jebik.v4i2.12485

[11] Herdiana, D. (2018). Sosialisasi Kebijakan Publik: Pengertian dan Konsep Dasar [Public Policy Community Outreach: Definition and Basic Concept]. Jurnal Ilmiah Wawasan Insan Akademik, I(3), 13-26. Retrieved from http://www.stiacimahi.ac.id/? page_id=1181\%0Ahttps://www.researchgate.net/publication/337485273_Sosialisasi_Kebijakan_Publik_Pengertian_dan_Konsep_Dasar

[12] Hermawan, H. (2019). Dampak Tambahan Modal Terhadap Kinerja Usaha Agribisnis Padi dalam Perspektif Penggunaan Input, Struktur biaya dan Pendapatan di Kabupaten Subang [Additional Impact of Capital on Rice Agribusiness Performance In the Perspective of Using Inputs, Structure of Costs and Revenues in Subang]. MAHATANI: Jurnal Agribisnis (Agribusiness and Agricultural Economics Journal), 2(1), 23-45. https://doi.org/10.52434/mja.v2i1.675

[13] Igirisa, I., Rahman, M., Abdussamad, J., Abdusamad, Z., \& Husain, A. K. (2020). Implementation of Development Policy for Livestock Farming Business in Gorontalo Regency, Gorontalo, Indonesia. Sys Rev Pharm 2020-11(12), 138-142. https://doi: 10.31838/srp.2020.12.23

[14] Kadji, Y, (2015). Formulasi dan Implementasi Kebijakan Publik: Kepemimpinan dan Perilaku Birokrasi dalam Fakta Realitas [Formulation and Implementation of Public Policy: Leadership and Bureaucratic Behavior in Reality]. Gorontalo. UNG Press

[15] Keputusan Menteri Pertanian RI (2018) - Keputusan Menteri Pertanian Nomor 472 tentang Lokasi Kawasan Pertanian Nasional [Decree of Minister of Agriculture Number 472 concerning Location of the National Agricultural Area]

[16] Khan, A. R., \& Khandaker, S. (2016). Critical insight into policy implementation and implementation performance. Public Policy and Administration, 15(4), 538-548. https://doi.org/10.13165/VPA-16-15-4-02

[17] Leng, G. xiao, Feng, X. long, \& Qiu, H. guang. (2021). Income effects of poverty alleviation relocation program on rural farmers in China. Journal of Integrative Agriculture, 20(4), 891-904. https://doi.org/10.1016/S2095-3119(20)63583-3

[18] Mitrawan F, \& Luthfi M. (2017). Analisis Sektor Unggulan Dan Hubungannya Dengan Perkembangan Perekonomian Wilayah Di Provinsi Sumatra Utara [Analaysis of Leading Sectors and Its Relation to Economic Development in North Sumatra Province]. Jurnal Bumi Indonesia, 6(1), 1-10. Retrieved from http://lib.geo.ugm.ac.id/ojs/index.php/jbi/issue/view/22 
[19] Nuraida, N., Rusli, B., Setianingrum, S., \& Rahmatunnisa, M. (2019). Evaluasi Kebijakan Percepatan Penanggulangan Kemiskinan Di Kabupaten Subang [Evaluation of Poverty Reduction Acceleration Policy in Subang Regency]. MIMBAR: Jurnal Penelitian Sosial Dan Politik, 8(1), 38. https://doi.org/ 10.32663/jpsp.v8i1.832

[20] Nurchasan. (2018). Monitoring dan Evaluasi Sebagai Pengendali Pelaksanaan Program dan Kegiatan [Monitoring and Evaluation as Controller of Program and Activity Implementation]. Buletin LAPAN Edisi Vol. 5 No. 2 (54-56). https://majalah.lapan.go.id/index. php/buletin/article/download/556/557/.

[21] PeraturanPresiden, R. I. (2010). Peraturan Presiden No 15 Tahun 2010 Tentang Percepatan Penanggulangan Kemiskinan [Presidential Regulation Number 15 of 2020 concerning Poverty Reduction Acceleration], https://peraturan.bpk.go.id/Home/Details/41038/perpres-no15-tahun-2010

[22] PeraturanPresiden RI (2015), Peraturan Persiden No 96 tahun 2015 tentang Perubahan atas Peraturan Presiden No 15 tahun 2010 tentang Percepatan Penanggulangan Kemiskinan [Presidential Regulation Number 96 of 2015 concerning Amendment to Presidential Regulation Number 15 of 2010 concerning Poverty Reduction Acceleration, https://peraturan.bpk.go.id/Home/Details/41841/perpres-no-96-tahun2015

[23] Peraturan D. (2015) - Peraturan Daerah Nomor 7 tahun 2015 tentang Program Percepatan Penanggulangan Kemiskinan berbasis Program Unggulan Daerah [Regional Regulation Number 7 of 2015 concerning Regional Leading Program-based Poverty Reduction Acceleration Program], https://peraturan. bpk.go.id/Home/Details/67429

[24] Setiyanto, A., Irawan, B., \& Dabukke, F. B. M. (2020). Pertanian Pascapandemi Covid-19 [Agriculture after COVID-19]. (3), 679-702. https://pse.litbang.pertanian.go.id/ind/pdffiles/33-BBRC-2020-V-1-2-ASY.pdf

[25] Sugiyono (2019) - Metode Penelitian Kuantitatif Kualitatif dan R\&D [Quantitative and Qualitative Research Method \& R\&D], Bandung: Alfa Beta

[26] Sutter, C., Bruton, G. D., \& Chen, J. (2019). Entrepreneurship as a solution to extreme poverty: A review and future research directions. Journal of Business Venturing, 34(1), 197-214. https://doi.org/10.1016/j.jbusvent.2018.06.003

[27] Wahab, S. A. (2017). Analisis Kebijaksanaan Negara dari Formulasi Ke Implementasi Kebijaksanaan Negara [State Wisdom Analysis from Its Formulation to Implementation]. Edisi Kedua. Jakarta: Bumi Aksara. 